\title{
Construction supply chain management: a scoping review
}

\author{
Gerenciamento da cadeia de suprimentos da construção: \\ uma revisão de escopo
}

\author{
Jefferson Augusto Krainer \\ Christiane Wagner Mainardes Krainer \\ Ana Celia Vidolin (P) \\ Frank Kiyoshi Hasse \\ Fabiano Barreto Romanel \\ Cezar Augusto Romano
}

1 Jefferson Augusto Krainer ${ }^{1}$ Universidade Tecnológica Federal do

Parana

Curitiba - PR - Brasil

${ }^{2}$ Christiane Wagner Mainardes

Krainer

2Universidade Tecnológica Federal do

Paraná

Curitiba - PR - Brasil

${ }^{3}$ Ana Celia Vidolin 3Universidade Tecnológica Federal do Paraná

Curitiba - PR - Brasil

${ }^{4}$ Frank Kiyoshi Hasse ${ }^{4}$ Universidade Tecnológica Federal do Paraná

Curitiba - PR - Brasil

${ }^{5}$ Fabiano Barreto Romanel ${ }^{5}$ Universidade Tecnológica Federal do Paraná

Curitiba - PR - Brasil

${ }^{6}$ Cezar Augusto Romano ${ }^{6}$ Universidade Tecnológica Federal do Paraná Curitiba - PR - Brasil

Recebido em 01/08/20 Aceito em 27/01/21

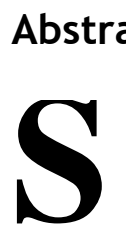

tudies related to construction supply chain management (CSCM) emerged in the mid-1990s to address the structural, economic and organizational nature typical of the construction industry. Previous researches sought to review the literature on CSCM, however, they usually focused on specific and well-defined issues. This article aimed to map the current areas and subareas of the CSCM. Adopting a bibliometric approach and following the PRISMA-ScR recommendations, a scoping review was carried out. With the help of the CiteSpace ${ }^{\odot}$ tool, the information was viewed as a co-citation network, providing a panoramic view of how the main publications are distributed and networked, forming research areas and subareas. The key documents and the main authors were identified; the current situation and the emerging points of interest in the CSCM field were also revealed. This article establishes a knowledge base for future research, which can help scholars and managers to identify authors, documents and journals to be considered when dealing with certain topics of the CSCM.

Keywords: Construction supply chain management. Co-citation network. Bibliometric study. CiteSpace. PRISMA-ScR.

\section{Resumo}

Estudos relacionados à gestão da cadeia de suprimentos da construção (GCSC) despontaram em meados dos anos 90 para atender à natureza estrutural, econômica e organizacional típica da indústria da construção. Pesquisas anteriores buscaram revisar a literatura sobre GCSC, no entanto, geralmente concentradas em questões pontuais e bem definidas. Este artigo tem como objetivo mapear as atuais áreas e subáreas do GCSC. Adotando-se uma abordagem bibliométrica e seguindo-se as recomendações PRISMA-ScR uma revisão de escopo foi realizada. Com auxílio da ferramenta CiteSpace ${ }^{\mathcal{O}}$ as informações foram visualizadas em forma de rede de cocitações, proporcionando uma visão panorâmica de como as principais publicações estão distribuídas e interligadas em rede, formando áreas e subáreas de pesquisa. Os documentos chaves e os principais autores foram identificados; a situação atual e os pontos de interesse emergentes no campo do GCSC também foram revelados. Este artigo estabelece uma base de conhecimento para pesquisas futuras, podendo auxiliar estudiosos e gestores a identificarem autores, documentos e periódicos que precisam ser considerados ao lidarem com determinados tópicos do GCSC.

Palavras-chave: Gerenciamento da cadeia de suprimentos da construção. Rede de cocitações. Estudo bibliométrico. CiteSpace. PRISMA-ScR.

KRAINER, J. A.; KRAINER, C. W. M.; VIDOLIN, A. C.; HASSE, F. K.; ROMANEL, F. B.; ROMANO, C. A. Construction supply chain management: a scoping review. Ambiente Construído, Porto Alegre, v. 21, n. 4, p. 343-365, out./dez. 343 2021.

ISSN 1678-8621 Associação Nacional de Tecnologia do Ambiente Construído. http://dx.doi.org/10.1590/s1678-86212021000400573 


\section{Introduction}

There are several studies on SCM from process-based manufacturing industries. Some of them even served as a basis for researchers dedicated to the construction industry. Akintoye (1995) and Agapiou et al. (1998), e.g., applied the Supply Chain Management (SCM) philosophy to construction supply chain (CSC) to set a relationship between local productivity and the improvement of materials. However, due to the transitory nature of construction projects, O'Brien (1999) pointed out that research related to manufacturing, while useful, does not apply easily to construction. Fernie and Tennant (2013) point out that the principles of supply chain management were neither generalized nor fully adopted in construction. In fact, CSC has its peculiarities: the existence of unique projects; composition by multiple self-protected and fragmented entrepreneurs; adverse and short-term transactional relationships; prevalence of competitive bidding; little information sharing; and little motivation for continuous learning (BEHERA; MOHANTY; PRAKASH, 2015). In addition, it works under cyclical demand (AKINTOYE; MCINTOSH; FITZGERALD, 2000) and the final product, supplied by order, receives strong influence from the customer (VRIJHOEF; KOSKELA, 2000).

Thus, studies related to construction supply chain management (CSCM) emerged in the mid-1990s to address the structural, economic and organizational nature typical of the construction industry. According to Xue et al. (2007), CSCM deals with the integration of the main members (customers/owner, designer, contractor, subcontractor and supplier) and construction business processes; emphasizes win-win, cooperative and lasting relationships; aims to improve construction performance and add value to the customer at a lower cost. Above all, the CSCM, like the SCM, brings an important change in the competitive model, considering that companies actually compete at the level of supply chains (VONDEREMBSE et al., 2006).

The literature has strongly recommended CSCM as a good solution to reduce waste, costs and conflicts, improve value for customers and increase productivity and competitiveness in the construction industry (O'BRIEN; LONDON; VRIJHOEF, 2004; ALBALOUSHI; SKIMORE, 2008; BANKVALL et al. 2010; BEHERA; MOHANTY; PRAKASH, 2015; BATTULA; NAMBURU; KONE, 2020). Kim and Nguyen (2020) consider that chain management is the future of the construction industry. However, compared to other industries, CSCM is a relatively new topic that challenges new research to expand existing knowledge (TIWARI; SHEPHERD; PANDEY, 2014; AL-WERIKAT, 2017).

The research already carried out sought to review the literature on the CSCM, but generally focused on specific and well-defined issues that help in the development of other related study projects. Volk, Stelgel and Schultmann (2014) and Utama et al. (2016), e.g., reviewed construction studies on building information modeling (BIM) and international projects, respectively; these studies, therefore, can help other researchers interested specifically in the themes of BIM and international projects. Thus, in order to promote the development of CSCM and bring a vision of the existing whole, general, broader and more comprehensive issues, which may be applicable to different study projects, should be addressed.

This article aimed to map the current CSCM research areas and subareas, based on a bibliometric approach. We seek answers to the following questions:

(a) (Q1) What are the main research areas/subareas?

(b) (Q2) Where are the most active areas?

(c) (Q3) What are the key documents?

(d) (Q4) What is the origin and development of the research areas? and

(e) (Q5) What are the promising study areas/subareas?

A bibliometric study was chosen because it introduces a systematic, transparent and reproducible process of identifying relevant works through objective and quantitative indicators (TRANFIELD; DENYER; SMART, 2003). The scoping review method was followed, which is also a systematic approach to synthesis of knowledge that allows mapping the literature (pointing out the general state of the research activity and clarifying areas of study) and identifying gaps with evidence where no research was conducted (ARKSEY; O'MALLEY, 2005; LEVAC; COLQUHOUN; O'BRIEN, 2010). The mapping of the literature as a scoping review is a preliminary study that allows the researcher to identify whether a complete systematic review is feasible (in terms of the number of existing researches), relevant (systematic reviews already carried out) and whether the effort to carry it out is justified (ARKSEY; O'MALLEY, 2005). Moreover, a scope study is

344 Krainer, J. A.; Krainer, C. W. M.; Vidolin, A. C.; Hasse, F. K.; Romanel, F. B.; Romano, C. A. 
an appropriate alternative when the researched literature is vast and complex (GRIMSHAW, 2008; MOHER; STEWART; SHEKELLE, 2015), as is the case with CSCM.

This research mapped the relevant literature of the last 30 years and made it possible, with the help of a bibliometric tool capable of revealing patterns and new advances in CSCM research, to visualize information as a co-citation network. The study guides managers and researchers about the existing research on the CSCM, enabling the detection of individual and specific interests (including research gap), assisting in decision-making in relation to the theoretical-methodological field, identifying the feasibility, relevance and the effort to carry out a complete systematic review, in short, facilitating the immersion of the scholar in a certain area or subarea of research.

\section{Method}

This study followed the scoping review method. The guidelines of Tricco et al. (2018) that propose Preferred Reporting Items for Systematic Review and Meta-Analyses (PRISMA) and their extensions for Scope Reviews (PRISMA-ScR) were adopted. In the following subsections, the items related to the method and activities carried out in this research were detailed.

\section{Research protocol}

As an initial step to guide the research, a protocol was developed that included the research objectives and questions, the selected initial studies and the source selection criteria. It also included the search and selection strategies for primary studies, as well as guidelines for the processes of extracting information and summarizing results. The protocol was registered at Open Science Framework (OSF) on May 12, 2020 (access link: http://osf.io/zm4qh).

\section{Eligibility criteria}

To be included in the review, the documents had to be related to construction supply chain management. To ensure the scope of the research and avoid omission of the target literature, "article", "proceedings paper" or "conference paper" and "review" or "conference review" were included, without language limitation, published in the period from 1990 to 2020.

\section{Research strategy and information sources}

The sequence of activities followed to carry out this research is described in Figure 1. After the research questions were defined, a bibliometric approach was chosen to conduct the present study.

\section{Figure 1 - Research strategy}

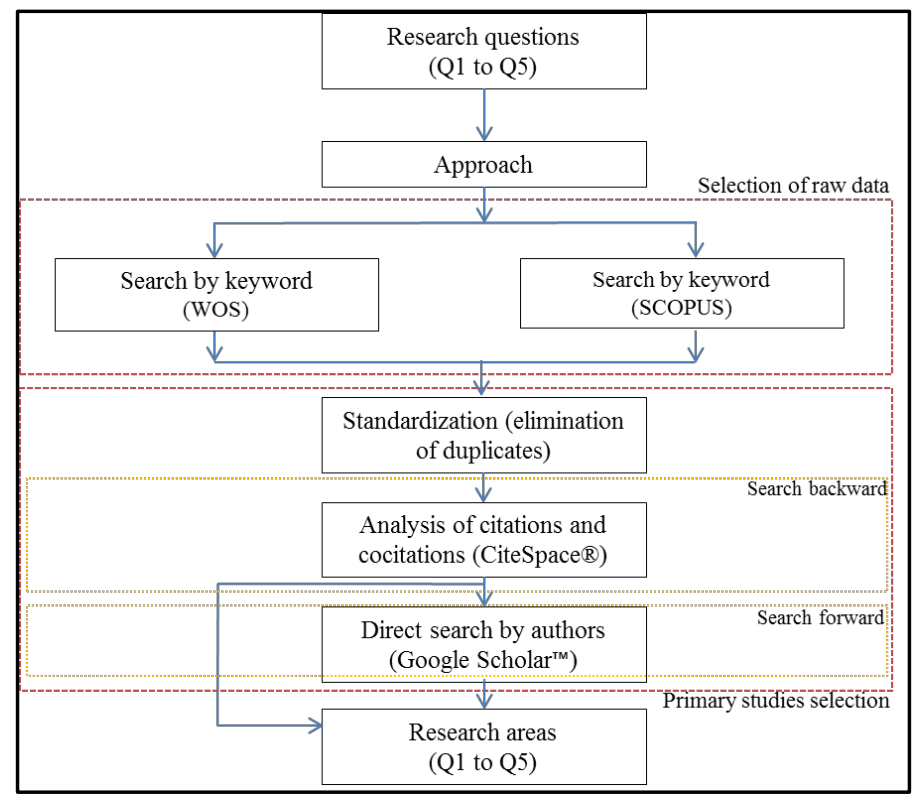


Data were selected in two stages:

(a) selection of raw data (search by keywords); and

(b) selection of primary studies (backward and forward search).

The congruence of the data obtained in the search backward and forward resulted in the areas related to CSCM.

In the first data selection (raw data selection), a search by keywords was carried out in the categories:

(a) title;

(b) abstract; and

(c) keyword.

The bases used to survey the raw data were the Web of Science (WoS) - Main Collection (Clarivate Analytics) and Scopus (Elsevier).

Each database was searched through its proprietary search engine interface, using the following search string: ["supply chain management" and ("construction industry" or "building" or "AEC")] or ["construction supply chain"]. The retrieval was carried out on May 13, 2020. Subsequently, the results were exported from WoS (in *.txt format) and Scopus (in *.RIS).

\section{Selection of primary studies}

In this stage (selection of primary studies), a backward search was carried out (review of references of the selected works) and forward search (review of what was published after an original work), as proposed by Webster and Watson (2002).

Data imported from WoS and Scopus were standardized (elimination of duplicates) and processed with the aid of CiteSpace ${ }^{\odot}$ v.6.7.R1 (open source bibliometric software, free and easy to handle). Through co-citation analysis, the software maps and explores trends in the literature, including identifying critical moments in the development of a field or domain (CHEN, 2006, 2013, 2016).

For the backward search, a co-citation analysis was used by counting the frequency of the pairs of documents simultaneously cited in a third work. The more often two papers are cited concurrently, the greater the likelihood of presenting associated content (SPINAK, 1996) and representing the knowledge structure of an area perceived by the researchers (GMÜR, 2003). Thus, there is similarity in content when two or more works are cited together in a third survey and the higher the frequency of co-citation, the closer the relationship between them and the greater the recognition by the researchers.

CiteSpace $^{\mathcal{O}}$ designed the co-citation networks that were formed, showing the salient traces of the related research activities. Each point represents a node (reference). Nodes are connected by co-citation links (lines that connect the nodes). The most prominent references (nodes) that appeared were those that were highly cited, so they refer to relevant/seminal works in the study area. The title, summary and keywords of the publications of the main clusters that were formed were examined. When it was not possible to extract the necessary information, the analysis was extended to the full text. The starting parameters were as follows:

(a) Time Slicing: 1990-2020;

(b) years per slice: " 1 ";

(c) source of term: title, abstract, author's keywords and keyword Plus;

(d) type of node: references; and

(e) selection criteria: the top 50 (most cited).

To identify and analyze the research areas, the following CiteSpace ${ }^{\odot}$ functions were used: clustering or grouping (approximation of objects with similar characteristics), labeling (context indication), burstness (detection of increase in citation) and "TimeLine" (reflects boundaries and trends). The citation burst relates a specific publication to an increase in citations, capturing an active area of research, or an emerging trend (CHEN, 2006). "Frequency" (counts the frequency of document citation), "Centrality" (translates the importance of intermediating nodes in the network), "burst" (identifies emerging interests), "modularity" (points out the clarity of the network structure), "Silhouette" (measures the homogeneity of the cluster members) and were some metrics used here to present the structure and distribution of scientific knowledge.

346 Krainer, J. A.; Krainer, C. W. M.; Vidolin, A. C.; Hasse, F. K.; Romanel, F. B.; Romano, C. A. 
In CiteSpace ${ }^{\odot}$, betweenness centrality scores are normalized to the range of $[0,1]$. A high centrality node (reference) establishes links with other documents. This index was used to discover and measure the importance of the literature.

Direct search by authors was the technique used for the forward search. It basically consisted of tracking the later works of the authors who had their works (related to CSCM) highlighted in the search backward, identifying whether they remained in the same research area, left for some derivation or even produced nothing more about the subject matter of study. For that, the titles that returned in the "advanced search" of the Google ScholarTM (GS) search engine were analyzed. Abstracts and full texts were accessed when necessary to extract complete information. We opted for GS because of its scope. There is strong evidence that it finds significantly more publications than Wos and Scopus in all study areas (HARZING, 2014; PRINS et al., 2016; MARTÍN-MARTÍN et al., 2018).

\section{Data charting}

A data graph form was discussed and developed (Figure 2) to determine which variables to extract after the second screening. Each extraction field has a data item, a value (numeric or semantic) that translates the investigated variable, and one or more sources that reveal the origin of the data (from where or how it was obtained).

As a pre-existing categorization was not identified in the literature, a specific and independent extraction of topics was chosen, as suggested by Petersen, Vakkalanka and Kuzniarz (2015). The authors analyzed the documents (title, keywords, abstract and, if necessary, the full text) to extract the main content (topic) of each study. To reduce bias, following the recommendation of Petticrew and Roberts (2008), all extractions were reviewed and reassessed by another reviewer (co-authors).

The topics were also used as a basis for building a subclassing scheme within the identified research areas. In this scheme, through an iterative process that involved, when necessary, merging and renaming topics, the documents were grouped into subcategories (specializations and derivations within the research areas).

Figure 2 - Data extraction form

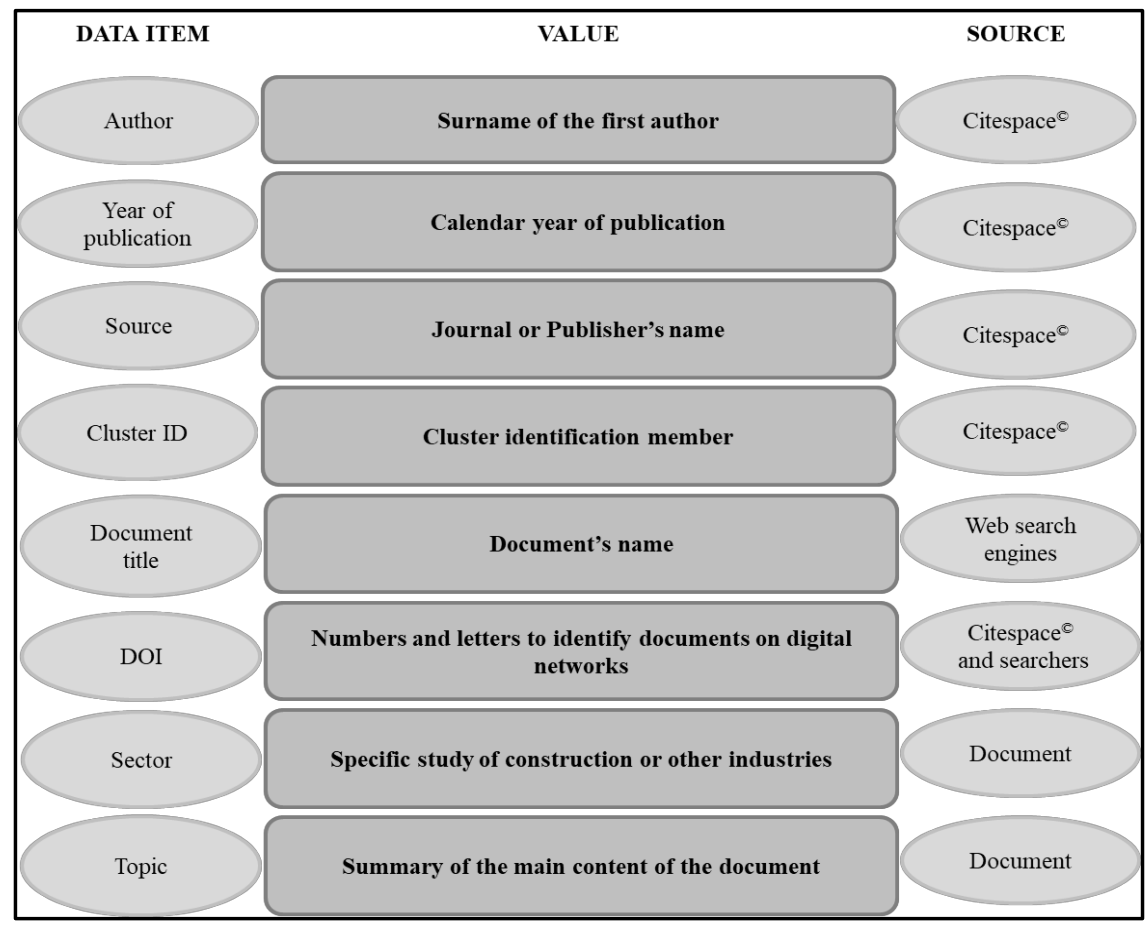




\section{Synthesis of results}

The information for each extracted item was tabulated. The analysis of the general results took place after the second screening. An overview of the CSCM research areas and subareas was presented. Co-citation networks, timelines and concept maps illustrate the findings. Concept maps were created with the help of the online tool GoConqr (https://www.goconqr.com). The individual characteristics of the key documents and the Top references were presented in a table. Finally, the findings of the scoping review were summarized and discussed.

\section{Results and discussions}

\section{Selection of sources}

At first, a total of 8,447 documents were retrieved (542 from WoS and 7,905 from Scopus). These documents were cited by 20,036 other works (3,065 from WoS and 16,971 from Scopus). After the first screening (elimination of duplicates), 4,467 documents were excluded, leaving a total of 15,569 documents, which resulted in 711,711 references. With the help of CiteSpace ${ }^{\odot}$ (second screening), we have grouped the 711,711 references from 15,569 documents into 13 main clusters containing 484 members (works). In this 484 works, 187 authors were identified, who published 1,872 works related to CSCM. Thus, 2,356 works were included in the scoping review: 484 composed the search backward and 1,872 gave rise the search forward. The source selection process is shown in Figure 3.

\section{Co-citation analysis}

The analysis of document co-citations was used to reveal the underlying structure (research areas) around the construction supply chain management and to show the number and authority of citations.

\section{Figure 3 - Source selection process}

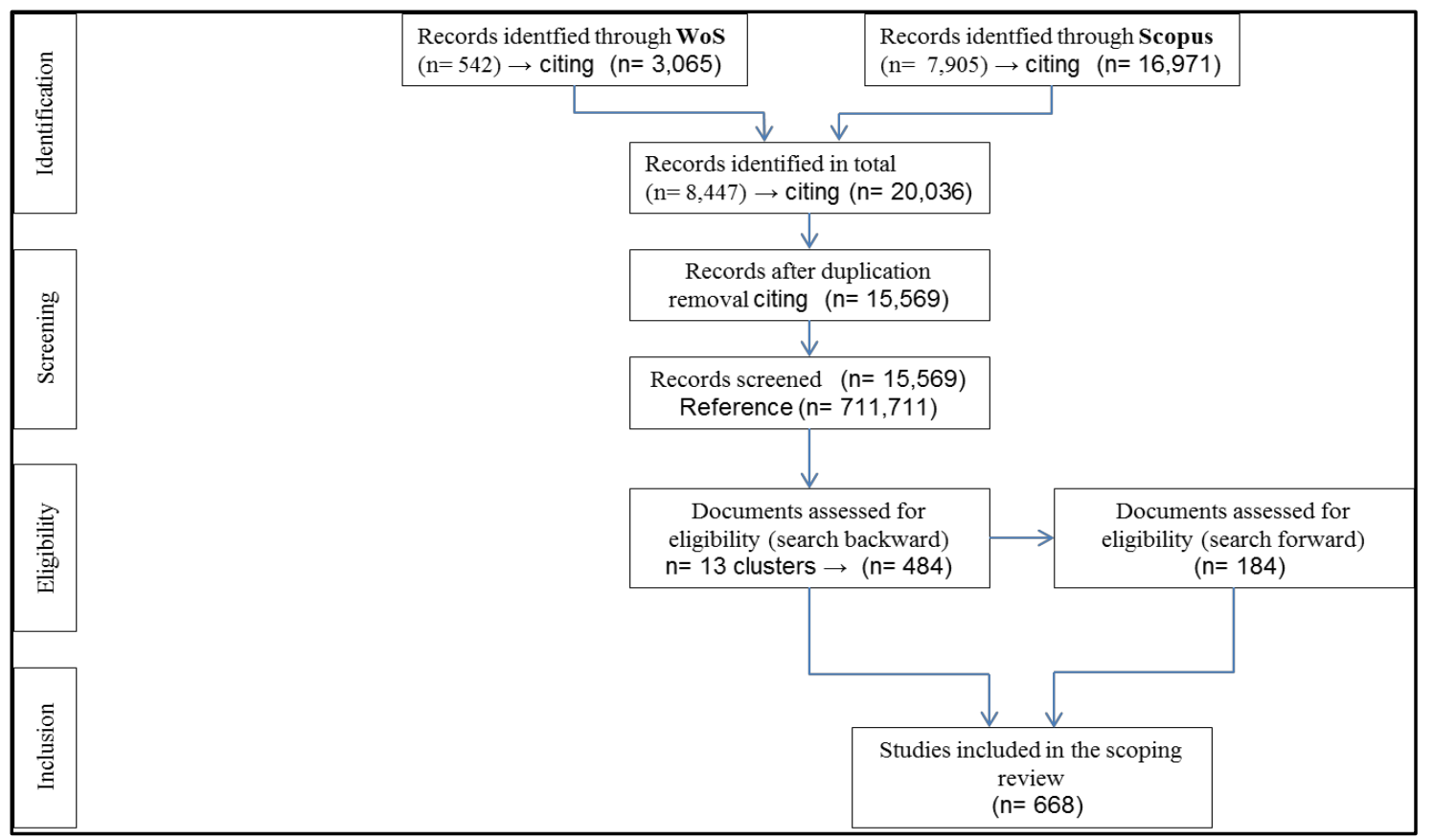

348 Krainer, J. A.; Krainer, C. W. M.; Vidolin, A. C.; Hasse, F. K.; Romanel, F. B.; Romano, C. A. 


\section{Document co-citation network}

The document co-citation network is shown in Figure 4. It contains 876 nodes and 3,475 links (lines that represent the document co-citation relationship). Each node represents a document (reference) and is marked with the name of the first author and the year of publication. The thickness of the nodes (some of them marked by concentric rings) shows the frequency of co-citation of the documents. The colors of the nodes and links (e.g., gray, blue, green, yellow, orange and red) correspond to different years from 1999 to 2020 of first occurrence. The references with high centrality and burst are highlighted by purple and red rings, respectively. The thicker the highlight, the stronger the burst and/or the centrality. In the presented network, the dominant color is gray, corresponding to occurrences from 1999 to 2010. Eastmann et al. (2011), Ghisellini, Cialani and Ulgiati (2016) and Kirchher, Reike and Hekkert (2017) correspond to the largest nodes in the network; they consequently had the highest citation frequencies (196, 174 and 118, respectively). Eastmann et al (2011) also had the highest burst strength (28.50). Briscoe and and Dainty (2005) emerged among the major centralities $(0.20)$.

\section{Clustering}

Subsequently, the CiteSpace ${ }^{\mathcal{O}}$ clustering function was used to identify groups, or rather, research areas of greater prominence. The clusters were preferably labeled using the keywords of the references, which function as the core and essence of the publications (HE; WANG, 2015). The reference titles were the second option. The internal components (subclassification) of each cluster (area) were also consulted (see Figure 5). The labels of the clusters, therefore, point to the context (research area) in which they are most cited. The log-likelihood ratio (LLR) algorithm was used to select, among the three highest scores that retrieved, the most appropriate label for the cluster, following exclusivity and coverage criteria, as recommended by Chen (2016). Clusters \#1, \#4, \#7, \#9, \#18 and \#19 received alternative labels (not corresponding to the automatic labeling option: Keyword, first line). A total of 174 clusters were identified, with 13 main (significant) co-citation clusters, as shown in Figure 5.

Figure 4 - Document co-citation network

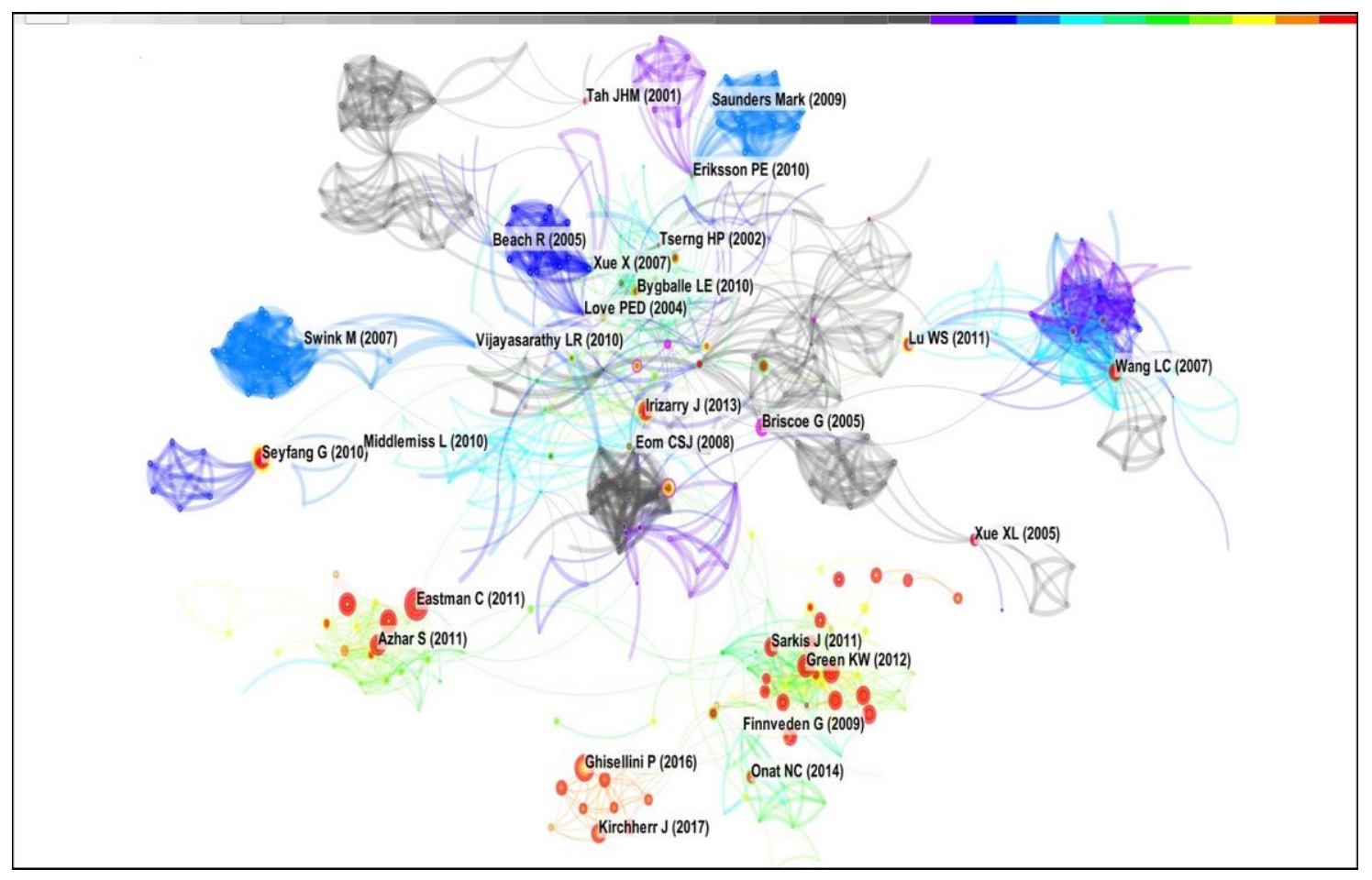


Figure 5 - Document co-citation network - clusters and descriptors

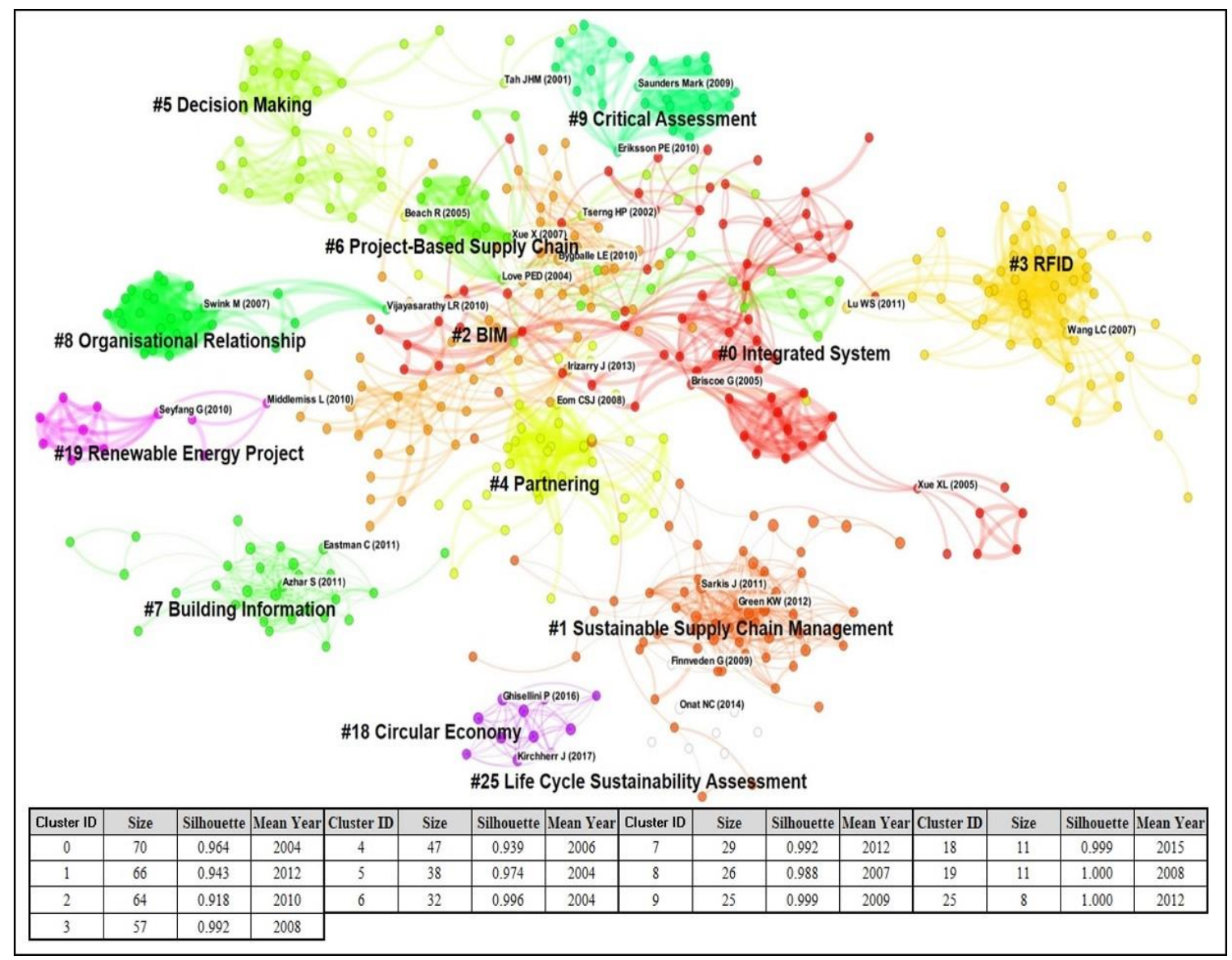

The cluster modularity $\mathrm{Q}$ at 0.9208 (close to 1.0 ) indicates that the network formed is partitioned into loosely coupled clusters (the different clusters are loosely coupled), or, in other words, the areas of the CSCM domain are clearly defined in terms of co-citation clusters. The 0.3316 silhouette suggests that the homogeneity (cohesion) of the 174 clusters, on average, is not very high. This is mainly due to the presence of several small clusters. However, the largest and most frequently cited clusters, main clusters (\#0 to \#9, $\# 18$, \#19 and \#25), the focus of our review, have sufficiently high silhouette values (with silhouette scores from 0.918 to 1 ). The descriptors (size, silhouette, average year and label) of the main clusters are listed in Figure 5. The size refers to the number of publications (members) within the cluster. There are 70 members in cluster \#0, which is the largest. The number in cluster \#25 was the lowest, with only eight members. The average year indicates whether the cluster is made up of newer or older documents. Thus, clusters \#0, \#5 and \#6 dating from 2004 contain older publications, while cluster \#18, from 2015, is composed predominantly of more recent documents. The oldest document is that of Hafeez et al. (1996), which is part of cluster \#39. These authors described the analysis and modeling of dynamic integration of a steel industry supply chain that served the construction industry.

\section{Origin and historical development of research areas}

To understand the origin, development and current status of the clusters (research areas), a visual analysis of the network's timeline (Figure 6) was made.

In the timeline view (Figure 6), it is observed that the research areas with more recent studies (close to 2019) are:

(a) circular economy (cluster \#18);

(b) sustainable supply chain management (\#1); and

(c) building information (\#7).

350 Krainer, J. A.; Krainer, C. W. M.; Vidolin, A. C.; Hasse, F. K.; Romanel, F. B.; Romano, C. A. 
Figure 6 - Timeline view of the main clusters

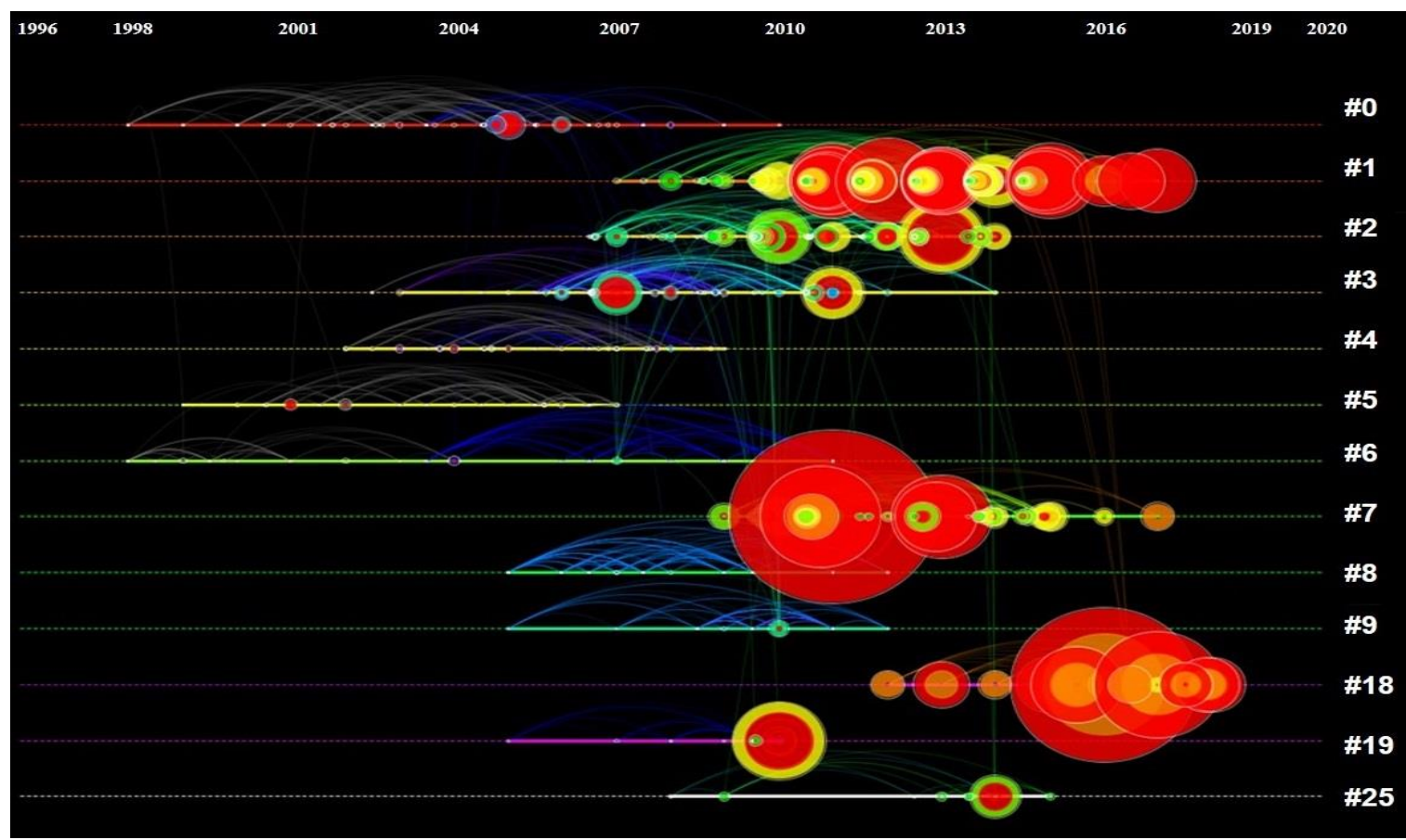

Areas such as decision making and partnering, e.g., have not had a volume of publications for a long time ( ince $\approx 2007$ and $\approx 2009$, respectively), which shows a discontinuity of connections.

\section{Research areas and sub-areas}

From the iterative analysis of the 484 publications that make up the 13 main clusters, a subclassification scheme (with percentage of occurrence) of the research areas emerged (see concept map in Figure 7). It started from a central topic (Construction Supply Chain Management) and branched it into subtopics (research subareas). So, e.g., in the area of renewable energy project (cluster \#18) there are studies on renewable energies $(50 \%)$, low carbon communities $(20 \%)$, sustainable construction $(20 \%)$ and climate change $(10 \%)$. The largest volume of studies $(15.57 \%)$ concerns subtopics (benefits, implementation, interoperability, GIS, RFID, e-business, lean construction, precast, sustainability, supplier management and economic impact) related to BIM (clusters \#2, \#3 and \#7). Subtopics related to partnership (barriers, practices, trust, critical success factors, performance indicators, procurement, public-private partnership and alliance) and integration (from SCM and suppliers) emerge in the sequence with $10.60 \%$ and $8.17 \%$ works, respectively. Economic issues, despite few studies (2.43\%) in general, are studied in several areas (Clusters $\# 0, \# 2, \# 5, \# 6, \# 7, \# 9$ and \#25). Finally, the analysis identified a preference for three major themes:

(a) information technology (26.27\%), distributed in clusters \#0, \#2; \#3, \#4; \#5, \#7 and \#8;

(b) relationship (25.65\%), found in clusters \#0, \#1 and \#2 to \#9; and

(c) sustainability (12.36\%), in clusters \#0, \#1, \#2, \#7, \#8, \#18, \#19 and \#25.

\section{Key documents}

Key documents (relevant to the study in the area) of each cluster refer to the 3 main documents with the highest frequency of co-citation. These documents, in fact, significantly influence the definition of the label of each cluster, which deserves attention. The citation burst and centrality scores also reveal the relevance of each document. Table 1 lists the key documents for each cluster (area) that includes the 3 most cited documents (see column "Freq"), the documents with the highest burst strength (in red) and those with the highest centrality (in green) in each research area. The source of the publications ("Source") and the topic ("Topic") are also informed. 
Figure 7 - Concept map - research areas and sub-areas

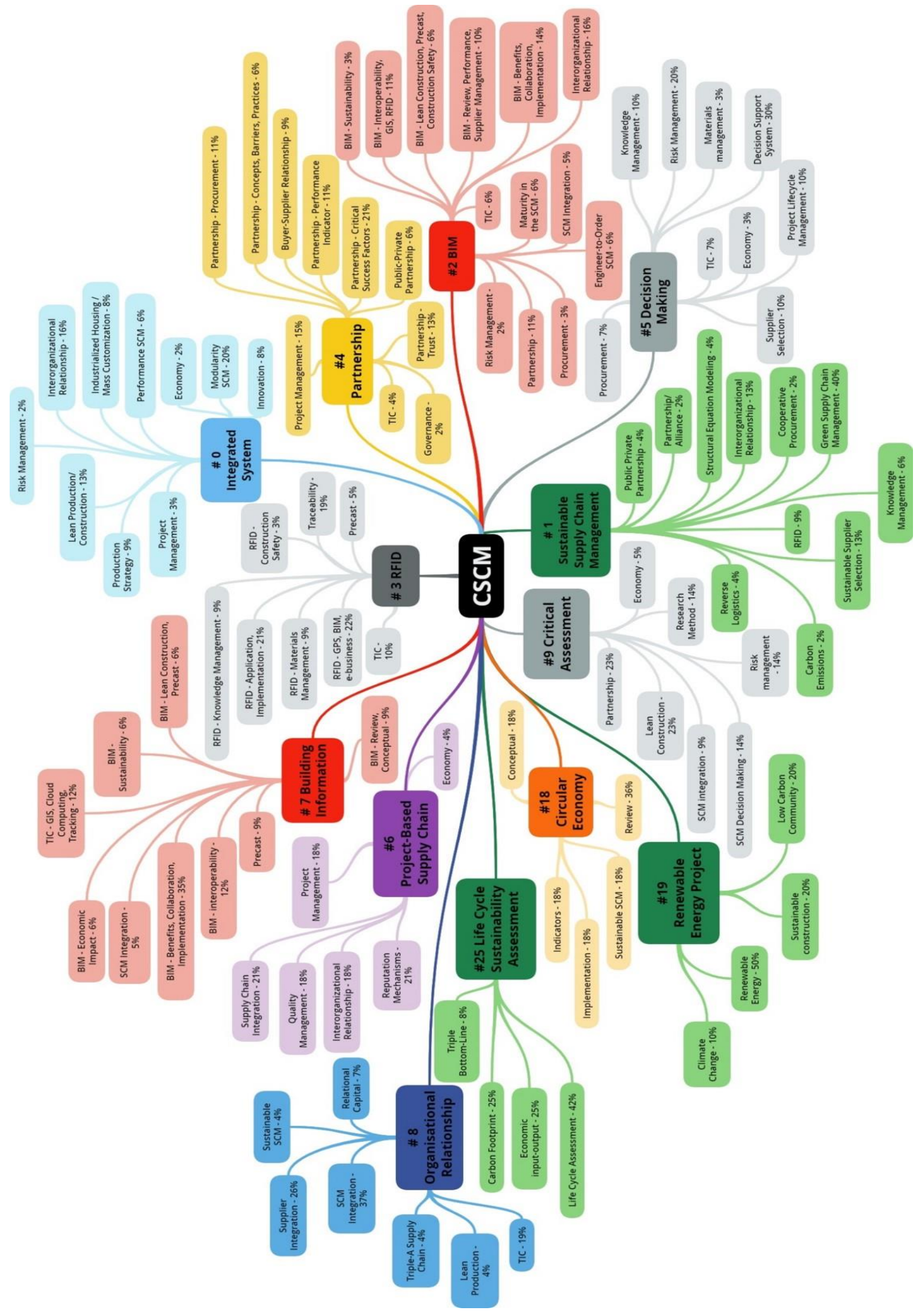


Table 1 - Key documents of the 13 main research areas (To be continued...)

\begin{tabular}{|c|c|c|c|c|c|c|}
\hline $\begin{array}{l}\text { Cluster } \\
\text { ID }\end{array}$ & Key Documents & Source & Freq & Burst & Cent & Topic (Supply Chain) \\
\hline \multirow{3}{*}{0} & Xue et al. (2005) & $\begin{array}{l}\text { AUTOMAT } \\
\text { CONSTR }\end{array}$ & 41 & 20.16 & 0.02 & $\begin{array}{l}\text { An Agent-based framework for } \\
\text { CSC coordination }\end{array}$ \\
\hline & $\begin{array}{c}\text { Briscoe and Dainty } \\
(2005)\end{array}$ & $\begin{array}{l}\text { SUPPLY CHAIN } \\
\text { MANAG }\end{array}$ & 23 & 11.50 & 0.20 & $\begin{array}{l}\text { Key principles to be followed } \\
\text { to achieve CSC integration }\end{array}$ \\
\hline & $\begin{array}{l}\text { Voordijk, } \\
\text { Meijboom and De } \\
\text { Haan (2006) }\end{array}$ & $\begin{array}{l}\text { INT J OPER } \\
\text { PROD MAN }\end{array}$ & 21 & 10.03 & 0.01 & Modularity in the CSC \\
\hline \multirow{5}{*}{1} & Green et al. (2012) & $\begin{array}{l}\text { SUPPLY CHAIN } \\
\text { MANAG }\end{array}$ & 98 & 15.84 & 0.01 & $\begin{array}{l}\text { Green supply chain } \\
\text { management practices: impact } \\
\text { on performance }\end{array}$ \\
\hline & $\begin{array}{l}\text { Sarkis, Zhu and Lai } \\
\text { (2011) }\end{array}$ & $\begin{array}{c}\text { INT J PROD } \\
\text { ECON } \\
\end{array}$ & 85 & 20.10 & 0.02 & $\begin{array}{l}\text { Green supply chain } \\
\text { management review }\end{array}$ \\
\hline & $\begin{array}{c}\text { Henseler, Ringle } \\
\text { and Sarstedt (2015) }\end{array}$ & $\begin{array}{l}\text { J ACAD MARK } \\
\text { SCIEN }\end{array}$ & 83 & & 0.00 & $\begin{array}{c}\text { Structural equation modelling } \\
\text { based on variance }\end{array}$ \\
\hline & $\begin{array}{c}\text { Hair, Ringle and } \\
\text { Sarstedt (2011) } \\
\end{array}$ & PLS-SEM & 75 & 23.90 & 0.00 & $\begin{array}{c}\text { Modelling partial least squares } \\
\text { structural equations }\end{array}$ \\
\hline & Meng (2012) & $\begin{array}{l}\text { INT J PROJ } \\
\text { MANAG }\end{array}$ & 47 & 18.61 & 0.12 & $\begin{array}{l}\text { Project performance and } \\
\text { relationship management }\end{array}$ \\
\hline \multirow{4}{*}{2} & $\begin{array}{l}\text { Irizarry, Karan and } \\
\text { Jalaei (2013) }\end{array}$ & $\begin{array}{l}\text { AUTOMAT } \\
\text { CONSTR }\end{array}$ & 83 & 24.65 & 0.05 & $\begin{array}{l}\text { CSC monitoring through the } \\
\text { integration of BIM and GIS }\end{array}$ \\
\hline & $\begin{array}{l}\text { Bygballe, Jahre and } \\
\text { Swärd (2010) }\end{array}$ & $\begin{array}{l}\text { J PURCH } \\
\text { SUPPLY } \\
\text { MANAG }\end{array}$ & 65 & 27.13 & 0.01 & Partnership in CSC: a review \\
\hline & Cheng et al. (2010) & $\begin{array}{l}\text { AUTOMAT } \\
\text { CONSTR }\end{array}$ & 39 & 15.36 & 0.00 & $\begin{array}{l}\text { A service oriented framework } \\
\text { for CSC integration }\end{array}$ \\
\hline & $\begin{array}{l}\text { Akintoye and Main } \\
\text { (2007) }\end{array}$ & $\begin{array}{l}\text { ENG CONSTR } \\
\text { ARCHIT MA }\end{array}$ & 7 & 3.53 & 0.25 & $\begin{array}{l}\text { Collaborative relationships in } \\
\text { construction (critical success } \\
\text { factors) }\end{array}$ \\
\hline \multirow{3}{*}{3} & $\begin{array}{l}\text { Lu, Huang and Li } \\
\text { (2011) }\end{array}$ & $\begin{array}{l}\text { AUTOMAT } \\
\text { CONSTR }\end{array}$ & 64 & 14.20 & 0.09 & $\begin{array}{l}\text { Applying RFID in construction } \\
\text { project management }\end{array}$ \\
\hline & $\begin{array}{l}\text { Wang, Lin and Lin } \\
\text { (2007) }\end{array}$ & $\begin{array}{l}\text { ADV ENG } \\
\text { INFORM }\end{array}$ & 54 & 22.20 & 0.02 & $\begin{array}{c}\text { A RFID-based CSC } \\
\text { management application }\end{array}$ \\
\hline & Shin et al. (2011) & $\begin{array}{l}\text { AUTOMAT } \\
\text { CONSTR }\end{array}$ & 21 & 11.39 & 0.00 & $\begin{array}{c}\text { RFC-based CSC management } \\
\text { based on RFC }\end{array}$ \\
\hline \multirow{3}{*}{4} & Chan et al. (2004) & $\begin{array}{c}\text { J CONSTR ENG } \\
\mathrm{M}\end{array}$ & 10 & 5.88 & 0.02 & $\begin{array}{l}\text { Critical success factors for } \\
\text { partnership projects }\end{array}$ \\
\hline & $\begin{array}{l}\text { Beach, Webster and } \\
\text { Campbell (2005) }\end{array}$ & $\begin{array}{l}\text { INT J PROJ } \\
\text { MANAG }\end{array}$ & 10 & 5.35 & 0.01 & $\begin{array}{l}\text { Partnerships: progress in the } \\
\text { construction industry and } \\
\text { implications for suppliers }\end{array}$ \\
\hline & $\begin{array}{l}\text { Eom, Yun and Paek } \\
\text { (2008) }\end{array}$ & $\begin{array}{c}\text { J CONSTR ENG } \\
M\end{array}$ & 10 & 4.87 & 0.08 & $\begin{array}{l}\text { Partnership: assessment and } \\
\text { management of subcontractors }\end{array}$ \\
\hline \multirow{3}{*}{5} & Tah and Carr (2001) & $\begin{array}{l}\text { ADV ENG } \\
\text { SOFTW }\end{array}$ & 19 & 12.30 & 0.04 & $\begin{array}{c}\text { Framework for project risk } \\
\text { knowledge management in the } \\
\text { CSC }\end{array}$ \\
\hline & $\begin{array}{l}\text { Tserng and Lin } \\
\qquad(2002)\end{array}$ & $\begin{array}{l}\text { AUTOMAT } \\
\text { CONSTR }\end{array}$ & 17 & 11.16 & 0.04 & $\begin{array}{l}\text { Subcontracting model and } \\
\text { accelerated acquisition for } \\
\text { construction projects }\end{array}$ \\
\hline & $\begin{array}{c}\text { Mitkus and } \\
\text { Trinkūniene (2006) }\end{array}$ & $\begin{array}{l}\text { J CIV ENG } \\
\text { MANG }\end{array}$ & 5 & & 0.01 & Decision support system \\
\hline
\end{tabular}


Table 1 - Key documents of the 13 main research areas (continuation)

\begin{tabular}{|c|c|c|c|c|c|c|}
\hline $\begin{array}{l}\text { Cluster } \\
\text { ID }\end{array}$ & Key Documents & Source & Freq & Burst & Cent & Topic (Supply Chain) \\
\hline \multirow{3}{*}{6} & $\begin{array}{c}\text { Love, Irani and } \\
\text { Edwards (2004a) }\end{array}$ & $\begin{array}{l}\text { SUPPLY CHAIN } \\
\text { MANAG } \\
\end{array}$ & 17 & 9.23 & 0.04 & $\begin{array}{c}\text { Integration of design and } \\
\text { project production processes }\end{array}$ \\
\hline & Xue et al. (2007) & $\begin{array}{c}\text { INT J PROJ } \\
\text { MANAG }\end{array}$ & 12 & 5.51 & 0.04 & $\begin{array}{l}\text { Coordination mechanisms in } \\
\text { the internet environment }\end{array}$ \\
\hline & Wong (1999) & $\begin{array}{l}\text { TOTAL QUAL } \\
\text { MANAGE }\end{array}$ & 10 & 6.74 & 0.00 & $\mathrm{CSCM}$ issues in total quality \\
\hline \multirow{3}{*}{7} & $\begin{array}{l}\text { Eastman et al. } \\
\text { (2011) }\end{array}$ & $\begin{array}{l}\text { John Wiley \& } \\
\text { Sons, Inc (Ed.) }\end{array}$ & 196 & 28.50 & 0.05 & BIM handbook: a guide \\
\hline & Azhar (2011) & $\begin{array}{l}\text { LEADERSHIP } \\
\text { MANAG ENG }\end{array}$ & 114 & 25.83 & 0.00 & $\begin{array}{l}\text { BIM: trends, benefits, risks, } \\
\text { and challenges }\end{array}$ \\
\hline & $\begin{array}{l}\text { Bryde, Broquetas } \\
\text { and Volm (2013) }\end{array}$ & $\begin{array}{c}\text { INT J PROJ } \\
\text { MANAG } \\
\end{array}$ & 95 & 21.46 & 0.00 & BIM: project benefits \\
\hline \multirow{3}{*}{8} & $\begin{array}{l}\text { Vijayasarathy } \\
\text { (2010) }\end{array}$ & $\begin{array}{l}\text { INT J PROD } \\
\text { ECON }\end{array}$ & 4 & & 0.01 & $\begin{array}{l}\text { Multidimensionality of supply } \\
\text { integration and its relational } \\
\text { background }\end{array}$ \\
\hline & $\begin{array}{c}\text { Koufteros, Edwin } \\
\text { Cheng and Lai } \\
(2007) \\
\end{array}$ & J OPER MANAG & 3 & & 0.00 & $\begin{array}{l}\text { Supplier integration (Theory of } \\
\text { social networks) }\end{array}$ \\
\hline & Sezen (2008) & $\begin{array}{l}\text { SUPPLY CHAIN } \\
\text { MANAG }\end{array}$ & 3 & & 0.05 & $\begin{array}{l}\text { Effects of design, integration } \\
\text { and information sharing on } \\
\text { supply chain performance }\end{array}$ \\
\hline \multirow{3}{*}{9} & Eriksson (2010) & $\begin{array}{l}\text { SUPPLY CHAIN } \\
\text { MANAG }\end{array}$ & 23 & 10.58 & 0.06 & $\begin{array}{c}\text { Lean construction } \\
\text { (collaboration and } \\
\text { performance) }\end{array}$ \\
\hline & $\begin{array}{l}\text { Saunders, Lewis } \\
\text { and Thornhill } \\
(2009) \\
\end{array}$ & $\begin{array}{l}\text { Pearson } \\
\text { Education }\end{array}$ & 3 & & 0.00 & $\begin{array}{l}\text { Research methods for business } \\
\text { students }\end{array}$ \\
\hline & Black (2010) & $\begin{array}{l}\text { John Wiley \& } \\
\text { Sons, Inc (Ed.) } \\
\end{array}$ & 2 & & 0.00 & $\begin{array}{c}\text { Business statistics: for } \\
\text { contemporary decision making }\end{array}$ \\
\hline \multirow{4}{*}{18} & $\begin{array}{l}\text { Ghisellini, Cialani } \\
\text { and Ulgiati (2016) }\end{array}$ & $\begin{array}{l}\text { J CLEANER } \\
\text { PROD }\end{array}$ & 174 & & 0.00 & $\begin{array}{c}\text { Circular economy } \\
\text { (characteristics and } \\
\text { perspectives) }\end{array}$ \\
\hline & $\begin{array}{l}\text { Kirchherr, Reike } \\
\text { and Hekkert (2017) }\end{array}$ & $\begin{array}{l}\text { RESOUR } \\
\text { CONSERV } \\
\text { RECYC } \\
\end{array}$ & 118 & & 0.00 & $\begin{array}{l}\text { Circular economy } \\
\text { (conceptualization) }\end{array}$ \\
\hline & $\begin{array}{l}\text { Lieder and Rashid } \\
\qquad(2016)\end{array}$ & $\begin{array}{l}\text { J CLEANER } \\
\text { PROD }\end{array}$ & 86 & & 0.00 & $\begin{array}{l}\text { Implementation of the circular } \\
\text { economy in manufacturing } \\
\text { systems }\end{array}$ \\
\hline & $\begin{array}{l}\text { Genovese } \text { et al. } \\
\text { (2017) }\end{array}$ & OMEGA & 41 & & 0.03 & $\begin{array}{l}\text { Sustainable supply chain } \\
\text { management and circular } \\
\text { economy }\end{array}$ \\
\hline \multirow{3}{*}{19} & Seyfang (2010) & ENERG POLICY & 92 & 20.33 & 0.02 & $\begin{array}{l}\text { Sustainable housing (carbon } \\
\text { reduction) }\end{array}$ \\
\hline & $\begin{array}{l}\text { Middlemiss and } \\
\text { Parrish (2010) }\end{array}$ & ENERG POLICY & 11 & 6.65 & 0.01 & $\begin{array}{c}\text { Grassroots initiatives and } \\
\text { creation of low carbon } \\
\text { communities }\end{array}$ \\
\hline & Walker et al. (2007) & $\begin{array}{l}\text { GLOBAL } \\
\text { ENVIRON } \\
\text { POLIT } \\
\end{array}$ & 5 & & 0.00 & $\begin{array}{c}\text { Renewable energies in the } \\
\text { United Kingdom (local } \\
\text { community) }\end{array}$ \\
\hline \multirow{3}{*}{25} & $\begin{array}{l}\text { Onat, Kucukvar and } \\
\text { Tatari (2014) }\end{array}$ & $\begin{array}{l}\text { BUILD } \\
\text { ENVIRON }\end{array}$ & 50 & 21.89 & 0.03 & $\begin{array}{c}\text { The carbon footprint of US } \\
\text { buildings (life cycle } \\
\text { assessment) }\end{array}$ \\
\hline & $\begin{array}{l}\text { Finnveden et al. } \\
(2009)\end{array}$ & $\begin{array}{l}\text { J ENVIRON } \\
\text { MANAGE }\end{array}$ & 10 & 5.27 & 0.04 & $\begin{array}{l}\text { Review of recent life cycle } \\
\text { assessment methods }\end{array}$ \\
\hline & $\begin{array}{c}\text { Kucukvar and } \\
\text { Tatari }(2013)\end{array}$ & $\begin{array}{l}\text { INT J LIFE } \\
\text { CYCLE ASS }\end{array}$ & 9 & & 0.00 & $\begin{array}{l}\text { Sustainability assessment for } \\
\text { the US construction industry }\end{array}$ \\
\hline
\end{tabular}

354 Krainer, J. A.; Krainer, C. W. M.; Vidolin, A. C.; Hasse, F. K.; Romanel, F. B.; Romano, C. A. 
The research papers included in this stage (Table 1) were published in journals $(93.02 \%)$ or in books. Journal articles have been published in 24 different Journals, with only 8 of them specialized in the Architecture, Engineering and Construction (AEC) industry: Building and Environment, Automation in Construction, Engineering, Construction and Architectural Management, Journal of Civil Engineering and Management, and Journal of Construction Engineering and Management. Automation in Construction, a journal focusing on construction technologies, was the source that published the largest number of documents ( 6 - clusters \#0, \#2, \#3 and \#5) of those listed in Table 1, followed by two journals specially dedicated to the publication of studies on management: Supply Chain Management ( 5 - clusters \#0, \#1, \#6; \#8 and \#9) and International Journal of Project Management (4 - clusters \#1, \#4; \#6 and \#7). Book documents (3) were published by two different publishers: John Wiley \& Sons, Inc (2) and Pearson Education (1).

The "Topic" column in Table 1 summarizes the main content of each publication. It should be noted that publications highlighted in blue do not refer exclusively to the CSC. This is because the references of the selected works were processed, that is, the documents referenced by authors (researchers) from AEC were considered in this research. So, e.g., in cluster \#1, sustainable supply chain management, the main representative documents were Green et al. (2012), Sarkis, Zhu e Lai (2011), Henseler, Ringle and Sarstedt (2015), Hair, Ringle and Sarstedt (2011), and Meng (2012). Only Meng (2012) refers exclusively to the construction supply chain. The first three works were the most cited in cluster \#1; Hair, Ringle and Sarstedt (2011) had the highest centrality (0.12) and Meng (2012) had the strongest citation burst (23.90). Green et al. (2012) investigated the impact of green supply chain management (GSCM) practices on performance. Sarkis, Zhu and Lai (2011) developed an organizational theoretical review on GSCM. Henseler, Ringle and Sarstedt (2015) talked about modeling structural equations based on variance.

As noted in clusters $\# 0, \# 4, \# 5, \# 6, \# 7, \# 9$, \#19 and \#25, the most cited document in each cluster was also, cumulatively, the strongest citation burst (see Table 1). Seyfang (2010), e.g., which dealt with sustainable housing (carbon reduction), aroused emerging interest (citation burst $=20.33$ ) and also had the highest frequency of citations (relevance to the scientific community) in the area of renewable energy project (cluster \#19). On the other hand, Ghisellini, Cialani and Ulgiati (2016) and Vijayasarathy (2010), respectively in clusters \#18 (circular economy) and \#8 (organizational relationship), had the highest frequency of citations (174 and 4), but did not even score any citation burst strength.

The centrality values identified in the present study (Table 1) are low (with scores from 0.01 to 0.25 ), indicating that, in general, there is low betweenness strength between the documents and reduced influence between the groups. In fact, many documents returned 0.00 centrality, such as Azhar (2011), Saunders, Lewins and Thornhill (2009) and Kucukvar and Tatari (2013). In most cases (clusters \#0, \#1, \#2, \#4, \#8, \#18 and \#25), even the highest centrality document did not match the one that received the most citations. Akintoye and Main (2007), e.g., had the highest centrality score (0.25) in cluster \#2 (and also in relation to the other clusters), but had a low citation frequency (7).

\section{Most active areas}

To detect the most active research areas, the CiteSpace $^{\odot}$ citation burst function was used, which is based on the Kleinberg (2003) algorithm. The citation burst encompasses two measures: the strength of the burst and the time (period) of the burst. The strength refers to the sudden increase in the frequency of reference citation and the time refers to the period of duration of this burst (which can extend for one or several years). Thus, we evaluated whether a specific publication (reference) was strongly cited (aroused the interest of the scientific community) at a certain moment (over a period of time). The characteristics of temporal distribution and strength variability (citation burst detection) may reflect the research fronts and the development trend in the domain of knowledge.

Table 2 shows the 25 references with, simultaneously, stronger citation bursts, of longer duration and that started first, in the period from 1999 to 2020. References with high values in the column "Burst strength" can be considered relevant in the field of CSCM. The "Topic" column summarizes the main content of each publication, "Begin", "End" refers to the duration of the citation burst and "ID" is the cluster number. Our analysis found that the paper by Wang et al. (2007), which deals with "RFID-based supply chain management application.", has the longest lasting and strongest citation burst (22.1952). This burst lasted 7 years, from 2008 to 2015, but it does not correspond to the longest time interval. The paper that remained for the longest time (8 years - from 2005 to 2013) was Xue et al. (2005), which deals with "The Agent-based framework for supply chain coordination", but corresponds to the second strongest citation burst (20.1625). 
Table 2 - Top 25 references with the strongest citation bursts in the period from 1999 to 2020

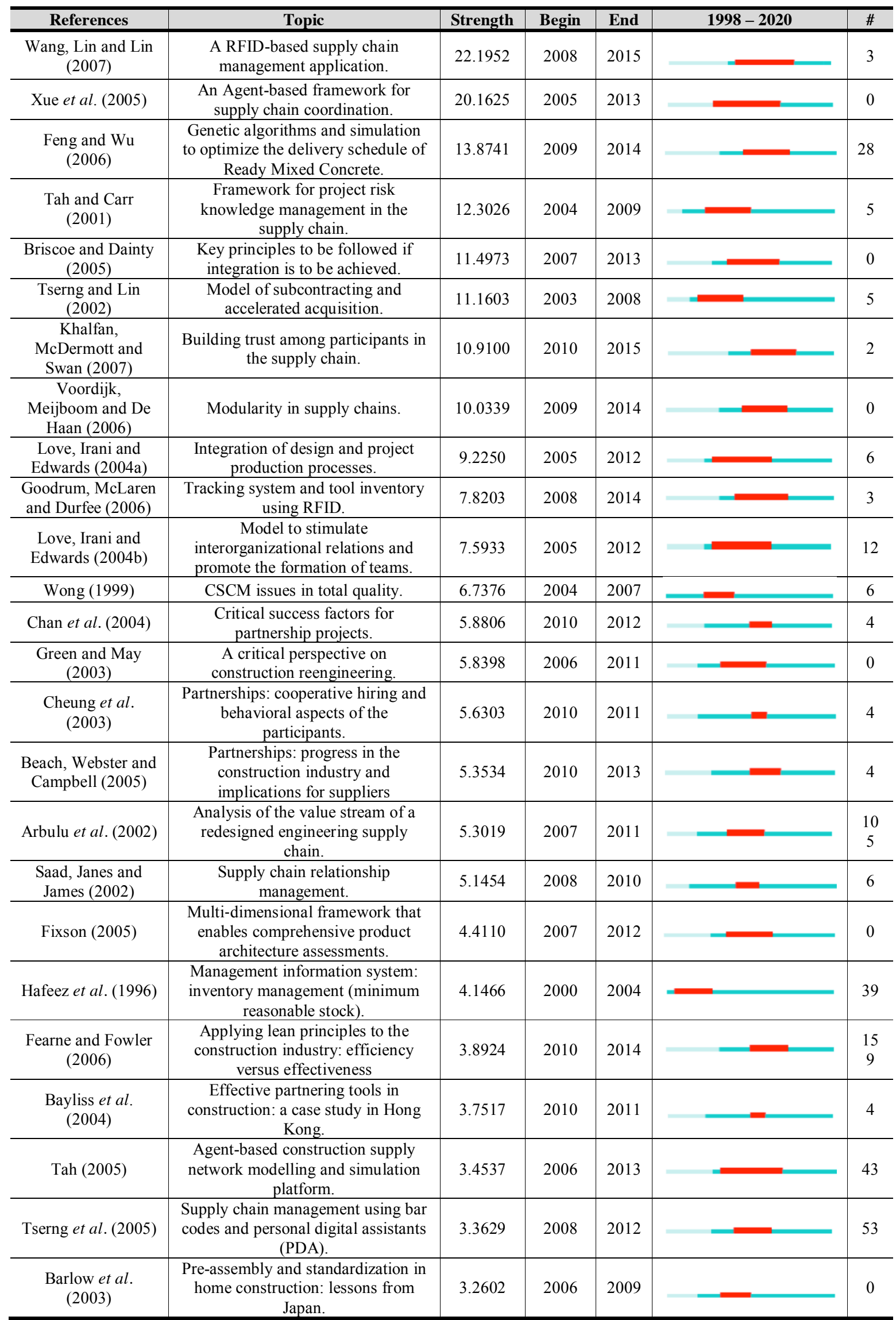

356 Krainer, J. A.; Krainer, C. W. M.; Vidolin, A. C.; Hasse, F. K.; Romanel, F. B.; Romano, C. A. 
More recent works tend to have weaker citation bursts. Except for Xue et al. (2005), the other references listed in Table 2 started their citation bursts at least one year after publication; e.g. Love, Irani and Edwards (2004a), Briscoe and Dainty (2005), Arbulu et al. (2002), Cheung et al. (2003), had a citation explosion started, respectively, 1, 2, 4 and 7 years after the publication of the article.

Partnership in construction is a recurring theme. Among the 25 references in Table 2, 4 refer to the partnership:

(a) Chan et al. (2004);

(b) Cheung et al. (2003);

(c) Beach, Webster and Campbell (2005); and

(d) Bayliss (2004).

RFID, supply chain integration and relationship management are other themes that are repeated in more than one reference. Wang et al. (2007) e Goodrum, Mclaren and Durfee (2006) dealt with RFID; Briscoe and Dainty (2005) and Love, Irani and Edwards (2004a) studied integration; and Love, Irani and Edwards (2004b) and Saad, Janes and James (2002) dedicated themselves to managing relationships in the construction supply chain. RFID and building trust, respectively in the works by Wang et al. (2007) and Khalfan, McDermott and Swan (2007), were the most recently consolidated themes (duration of time until 2015).

To track the recent development of knowledge, the 133 top references with the strongest citation bursts were considered and the first 10 that evolved until 2020 were listed (Table 3). The paper by Mathiyazhagan et al. (2013), which dealt with sustainable supplier selection initiatives, has the most current citation burst (extending until 2020), the longest lasting (4 years) and the strongest (11.5045). Research pertaining to sustainability/green chain (cluster \#1), starting in 2016, saw an increase in demand (aroused greater interest), followed, starting in 2017, by BIM (\#7) and structural equation modeling (\#1).

Table 3 - Top 10 among the 133 top references with the strongest citation bursts in the period from 1998 to 2020

\begin{tabular}{|c|c|c|c|c|c|c|}
\hline References & Topic & Strength & Begin & End & $1998-2020$ & $\#$ \\
\hline $\begin{array}{c}\text { Govindan, } \\
\text { Khodaverdi and } \\
\text { Jafarian (2013) }\end{array}$ & $\begin{array}{l}\text { Sustainable supplier } \\
\text { selection initiatives }\end{array}$ & 11.5045 & 2016 & 2020 & - & 1 \\
\hline $\begin{array}{c}\text { Mathiyazhagan et } \\
\text { al. (2013) }\end{array}$ & $\begin{array}{l}\text { GSCM (barriers to } \\
\text { implementation) }\end{array}$ & 10.8679 & 2016 & 2020 & & 1 \\
\hline $\begin{array}{c}\text { Eastman et al. } \\
(2011)\end{array}$ & $\begin{array}{l}\text { BIM handbook: a } \\
\text { guide }\end{array}$ & 28.5065 & 2017 & 2020 & & 7 \\
\hline Azhar (2011) & $\begin{array}{l}\text { BIM (trends, } \\
\text { benefits, risks, and } \\
\text { challenges) }\end{array}$ & 25.8329 & 2017 & 2020 & & 7 \\
\hline $\begin{array}{l}\text { Bryde, Broquetas } \\
\text { and Volm (2013) }\end{array}$ & BIM (benefits) & 21.4653 & 2017 & 2020 & & 7 \\
\hline Eadie et al. (2013) & BIM (deployment) & 17.1228 & 2017 & 2020 & $=$ & 7 \\
\hline $\begin{array}{l}\text { Govindan et al. } \\
\text { (2015) }\end{array}$ & $\begin{array}{l}\text { Evaluation and } \\
\text { selection of green } \\
\text { suppliers }\end{array}$ & 16.8950 & 2017 & 2020 & 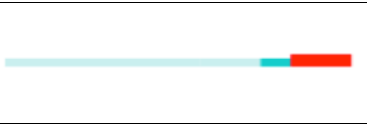 & 1 \\
\hline $\begin{array}{l}\text { Yazdani et al. } \\
\quad(2017)\end{array}$ & $\begin{array}{c}\text { Green supplier } \\
\text { selection }\end{array}$ & 15.9842 & 2017 & 2020 & 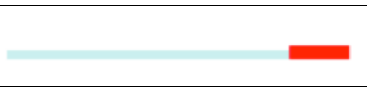 & 1 \\
\hline $\begin{array}{l}\text { Carter and Easton } \\
\qquad(2011)\end{array}$ & $\begin{array}{l}\text { GSCM: evolution } \\
\text { and future } \\
\text { directions } \\
\end{array}$ & 14.6202 & 2017 & 2020 & & 1 \\
\hline $\begin{array}{l}\text { Hair, Ringle and } \\
\text { Sarstedt (2011) }\end{array}$ & $\begin{array}{l}\text { Structural equation } \\
\text { modelling } \\
\text { (theoretical criteria) }\end{array}$ & 23.9012 & 2018 & 2020 & & 1 \\
\hline
\end{tabular}


Figure 8 - Concept map - search forward

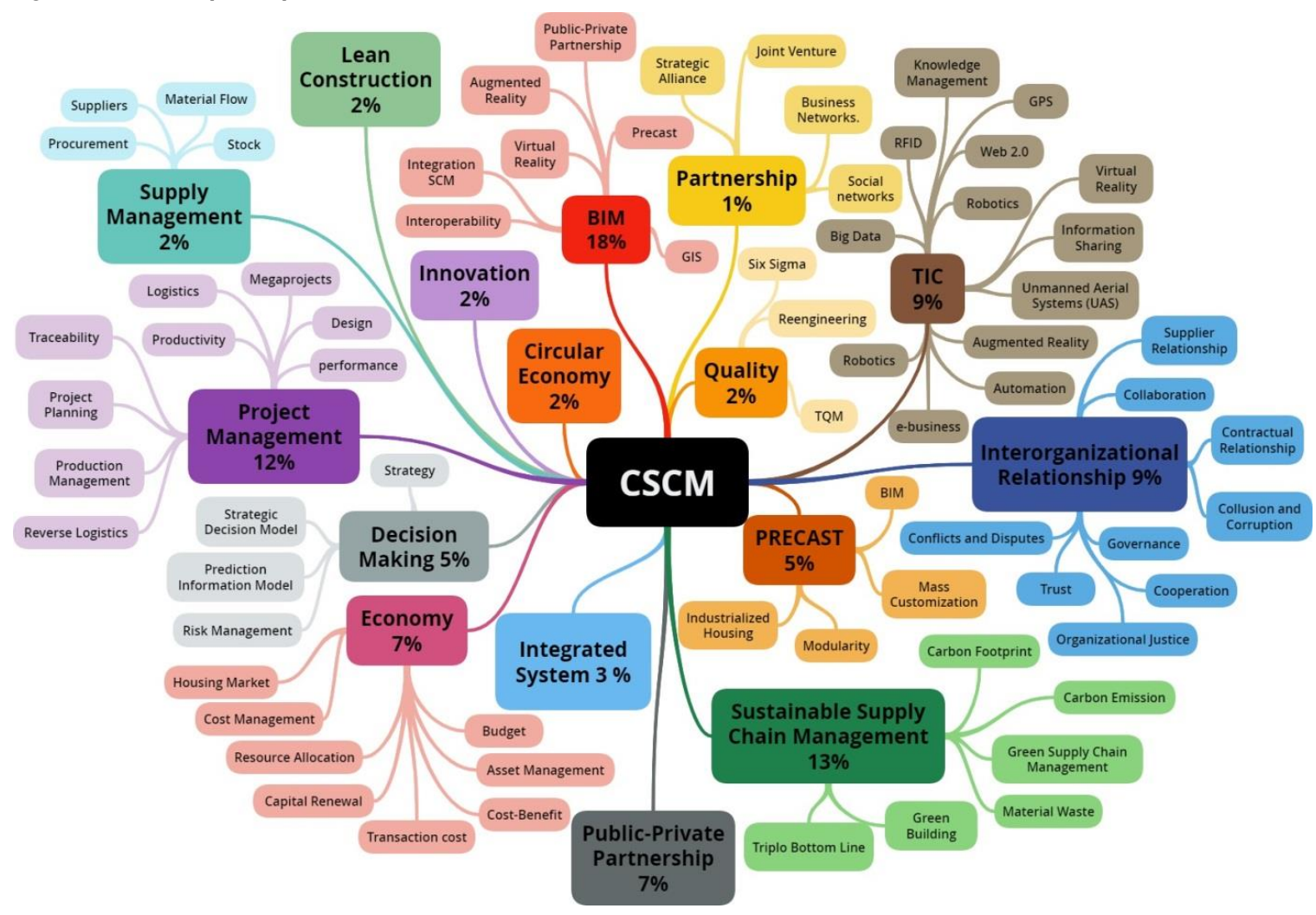

\section{Authors with search forward}

Among the 484 works selected in search backward, 1,872 works related to the CSCM were identified. These works were classified into 19 areas. Figure 8 illustrates the representation of these 19 areas (with percentage of occurrence) and, when applicable, the internal details (description of the subareas). BIM (augmented reality, GIS, interoperability, integration and precast) corresponds to the area with the largest number of studies $(18 \%)$, followed by GSCM (13\%). New areas emerged (blockchain, social capital and construction 4.0) and others visibly intensified (project management, interorganizational relationship, public-private partnership and precast).

\section{Discussion of results}

To map the current CSCM research areas and subareas, searches were carried out for references backwards (in order to attain greater understanding of the origins and consolidation of areas/subareas) and for authors forward (to identify current areas/subareas - greater interest). Through the analysis of co-citations, representations of the structure of the CSCM were produced. CiteSpace ${ }^{\odot}$ designed the co-citation networks (Figure 1). The data structure of WoS and Scopus, bases that encompass a diversity of quality documents from the AEC allowed the analysis of references, including the extension of the research to include books, journals and conferences from other bases.

According to the analysis of co-citations, in line with what O'Brien, London and Vrijhef (2004) refer to, the publication of the research on CSCM began in the middle of the 90s. Hafeez et al. (1996) was the oldest work identified in this study. The summary of the main results linked to the questions (Q1 to Q5) is presented below:

(a) Q1 (research areas/subareas):

- 13 areas and 106 sub-areas were identified, according to the distribution shown in Figure 7;

- integrated system is the area that grouped the largest number of works (70);

- integrated system, decision-making and project-based supply chain are the oldest areas (average year 2004), while circular economy is the most recent area (2015);

358 Krainer, J. A.; Krainer, C. W. M.; Vidolin, A. C.; Hasse, F. K.; Romanel, F. B.; Romano, C. A. 
- sub-areas related to BIM, partnership and integration are the most productive; and

- information technology, relationship and sustainability are the three major themes studied in the CSCM.

(b) Q2 (most active areas):

- the most active research fronts are highlighted in Tables 2 and 3;

- integrated system is the area that presented the largest number of topics of emerging interest; and - partnership in construction, RFID, supply chain integration and relationship management are recurring themes.

(c) Q3 (key documents):

- key documents (relevant, therefore must-read documents) for each area are listed in Table 1. These documents, although they do not refer exclusively to the CSC, are highly cited in their respective areas or intermediate other studies;

- authors from the AEC industry refer to authors from other industries, which shows attempts to import and/or adapt concepts, theories, models and frameworks;

- non-specialized journals in the AEC industry also often publish articles on CSCM. In this study, we even identified only 8 specialized journals that published key documents;

- automation in Construction is the Journal that published the largest number of key articles (6);

- highly cited documents do not always arouse emerging interest (citation burst); and

- in general, the key documents analyzed have low centrality, which translates into low influence among the documents and the absence of revolutionary studies.

(d) Q4 (origin and development of areas):

- the timeline view (Figure 6) reveals the origin (beginning of connections) and the development of each area. Integrated system, e.g., appeared in 1998 and had a marked development until 2010;

- Figure 8 shows the current areas/subareas of greatest interest; and

- circular economy, sustainable supply chain management and building information are areas that have greater recent attractiveness.

(e) Q5 (promising areas):

- table 3 lists the topics related to two promising areas (of increasing interest): sustainable SCM and building information;

- other areas/subareas of increasing interest are represented in Figure 8. New areas have emerged (blockchain, social capital and construction 4.0) and others have visibly intensified (project management, interorganizational relationship, public-private partnership and precast);

- research related to BIM, sustainability/green chain, interorganizational relationship and structural equation modeling had a recent increase in demand;

- there is a certain predilection for the use of structural equation modeling techniques, such as the works of Hanseler, Ringle and Sarstedt (2015) and Hair et al. (2011); and

- there is a lack of studies on economic issues, blockchain, social capital and construction 4.0 related to CSCM, and are therefore fertile fields for the development of new works.

\section{Conclusions}

This article is a scoping review that followed the PRISMA-Scr recommendations to map the current areas and subareas of research in the scientific field of CSCM. The results show that CSCM has been continuously developing and attracting more and more researchers' attention. The number of documents produced $(2,356$ studies) and the diversity of related areas (forward search identified 19 areas, some of them emerging) support this discovery.

Based on bibliometric records (711,711 references), a systematic and comprehensive review of the existing global research status on the CSCM is provided. This study uses a bibliometric approach to analyze information with the help of CiteSpace ${ }^{\odot}$. The key documents and the main authors were identified; the 
current situation and emerging points of interest in the CSCM field have been revealed. It also presented a panoramic view of how the main publications are distributed and networked, forming research areas and subareas. Moreover, this article establishes a knowledge base for future research, which can help scholars and managers to identify authors, documents and journals to be considered when dealing with a specific topic of CSCM. It also serves as a guide for future systematic reviews dedicated to revealing the progress of related research.

This research, therefore, in addition to providing a robust method of mapping the literature, can encourage the development of the CSCM, insofar as it serves as inspiration, consultation or a starting point for new studies. It also plays a key role in identifying the current focus of study and in discussing the future directions of CSCM. In fact, the expansion and deepening of studies on CSCM can benefit society as a whole, since improved management offers the opportunity to overcome challenges such as wasted resources, low productivity and excessive costs, time and conflicts.

The range of time covered (30 years - 1990 to 2020) and the removal of language and document type limitations (to include articles, proceedings and books), as well as comprehensive literature search, are an important strength of this study. Despite this, it is possible that research on CSCM also exists under different terminologies that were not captured in this review. The input data limit the present study. Other keywords can be included, removed and/or rearranged in future searches. Further analysis of the studies included in the review, using, e.g., a meta-analytical perspective, could provide more information. Future studies may focus on this meta-analysis.

The bases used to survey the raw data were WoS and Scopus. This limits research to the extent of these bases. Future research should consider the integration of other databases, such as Compendex (Engineering Village) and Engineering Database - Engineering Journals (PROQUEST).

The data supporting the conclusions of this article are presented in tables available at: http://osf.io/zm4qh.

\section{References}

AGAPIOU, A. et al. The role of logistics in the materials flow control process. Construction Management and Economics, v. 16, n. 2, p. 131-137, 1998.

AKINTOYE, A. Just-in-Time application and implementation for building material management. Construction Management and Economics, v. 13, n. 2, p. 105-113, 1995.

AKINTOYE, A.; MAIN, J. Collaborative relationships in construction: the UK contractors' perception. Engineering, Construction and Architectural Management, v. 14, n. 6, p. 597-617, 2007.

AKINTOYE, A.; MCINTOSH, G.; FITZGERALD, E. A survey of supply chain collaboration and management in the UK construction industry. European Journal of Purchasing and Supply Management, v. 6, n. 3-4, p. 159-168, 2000.

AL-WERIKAT, D. G. Supply chain management in construction revealed. International Journal of Scientific and Technology Reserarch, v. 6, n. 3, p. 106-110, 2017.

ALBALOUSHI, H.; SKITMORE, M. Supply chain management in the UAE construction industry. International Journal of Construction Management, v. 8, n. 1, p. 53-71, 2008.

ARBULU, R. J. et al. Contributors to lead time in construction supply chains: case of pipe supports used in power plants. In: WINTER SIMULATION CONFERENCE, San Diego, 2002. Proceedings [...] San Diego: IEEE, 2002.

ARKSEY, H.; O’MALLEY, L. Scoping studies: towards a methodological framework. International Journal of Social Research Methodology, v. 8, n. 1, p. 19-32, 2005.

AZHAR, S. Building Information Modeling (BIM): trends, benefits, risks, and challenges for the AEC industry. Leadership and Management in Engineering, v. 11, n. 3, p. 241-252, 2011.

BANKVALL, L. et al. Interdependence in supply chains and projects in construction. Supply Chain Management, v. 15, n. 5, p. 385-393, 2010.

BARLOW, J. et al. Choice and delivery in housebuilding: lessons from Japan for UK housebuilders.

Building Research and Information, v. 31, n. 2, p. 134-145, 2003. 
BATTULA, V. R.; NAMBURU, S. K.; KONE, V. A study on factors involved in implementation of supply chain management in construction industry. Materials Today: Proceedings, v. 33, Part 1, p. 446-449, 2020.

BAYLISS, R. et al. Effective partnering tools in construction: a case study on MTRC TKE contract 604 in Hong Kong. International Journal of Project Management, v. 22, n. 3, p. 253-263, 2004.

BEACH, R.; WEBSTER, M.; CAMPBELL, K. M. An evaluation of partnership development in the construction industry. International Journal of Project Management, v. 23, n. 8, p. 611-621, 2005.

BEHERA, P.; MOHANTY, R. P.; PRAKASH, A. Understanding construction supply chain management. Production Planning and Control, v. 26, n. 16, p. 1332-1350, 2015.

BLACK, K. Business Statistics: for contemporary decision making. $6^{\text {th }}$ ed. New York: John Wiley \& Sons, 2010.

BRISCOE, G.; DAINTY, A. Construction supply chain integration: an elusive goal? Supply Chain Management, v. 10, n. 4, p. 319-326, 2005.

BRYDE, D.; BROQUETAS, M.; VOLM, J. M. The project benefits of building information modelling (BIM). International Journal of Project Management, v. 31, n. 7, p. 971-980, 2013.

BYGBALLE, L. E.; JAHRE, M.; SWÄRD, A. Partnering relationships in construction: a literature review. Journal of Purchasing and Supply Management, v. 16, n. 4, p. 239-253, 2010.

CARTER, C. R.; EASTON, P.L. Sustainable supply chain management: evolution and future directions. International Journal of Physical Distribution and Logistic Management, v. 41, n. 1, p. 46-62, 2011.

CHAN, A. P. C. et al. Exploring critical success factors for partnering in construction projects. Journal of Construction Engineering and Management, v. 130, n. 2, p. 188-198, 2004.

CHEN, C. CiteSpace II: detecting and visualizing emerging trends and transient patterns in scientific literature. Journal of the American Society for Information Science and Technology, v. 57, n. 3, p. 359377, 2006.

CHEN, C. Citespace: a practical guide for mapping scientific literature. Hauppauge: Nova Science Publishers, 2016.

CHEN, C. Mapping scientific frontiers: the quest for knowledge visualization. $2^{\text {nd }}$ ed. London: Springer, 2013.

CHENG, J. C. P. et al. A service oriented framework for construction supply chain integration. Automation in Construction, v. 19, n. 2, p. 245-260, 2010.

CHEUNG, S. O. et al. Behavioral aspects in construction partnering. International Journal of Project Management, v. 21, n. 5, p. 333-343, 2003.

EADIE, R. et al. BIM implementation throughout the UK construction project lifecycle: an analysis. Automation in Construction, v. 36, p. 145-151, 2013.

EASTMAN, C. et al. BIM Handbook: a guide to building information modeling for owners, managers, designers, engineers and contractors. $2^{\text {nd }}$ ed. Hoboken: John Wiley \& Sons, 2011.

EOM, C. S. J.; YUN, S. H.; PAEK, J. H. Subcontractor evaluation and management framework for strategic partnering. Journal of Construction Engineering and Management, v. 134, n. 11, p. 842-851, 2008.

ERIKSSON, P. E. Improving construction supply chain collaboration and performance: a lean construction pilot project. Supply Chain Management, v. 15, n. 5, p. 394-403, 2010.

FEARNE, A.; FOWLER, N. Efficiency versus effectiveness in construction supply chains: the dangers of "lean" thinking in isolation. Supply Chain Management, v. 11, n. 4, 2006.

FENG, C. W.; WU, H. T. Integrating fmGA and CYCLONE to optimize the schedule of dispatching RMC trucks. Automation in Construction, v. 15, n. 2, p. 186-199, 2006.

FERNIE, S.; TENNANT, S. The non-adoption of supply chain management. Construction Management and Economics, v. 31, n.10, p. 1038-1058, 2013.

FINNVEDEN, G. et al. Recent developments in life cycle assessment. Journal of Environmental Management, v. 91, n. 1, p. 1-21, 2009. 
FIXSON, S. K. Product architecture assessment: a tool to link product, process, and supply chain design decisions. Journal of Operations Management, v. 23, n. 3-4, p. 345-369, 2005.

GENOVESE, A. et al. Sustainable supply chain management and the transition towards a circular economy: evidence and some applications. Omega, v. 66, p. 344-357, 2017.

GHISELLINI, P.; CIALANI, C.; ULGIATI, S. A review on circular economy: the expected transition to a balanced interplay of environmental and economic systems. Journal of Cleaner Production, v. 114, p.1132, 2016.

GMÜR, M. Co-citation analysis and the search for invisible colleges: a methodological evaluation.

Scientometrics, v. 57, n. 1, p. 27-57, 2003.

GOODRUM, P. M.; MCLAREN, M. A.; DURFEE, A. The application of active radio frequency identification technology for tool tracking on construction job sites. Automation in Construction, v. 15, n. 3, p. 292-302, 2006.

GOVINDAN, K. et al. Multicriteria decision making approaches for green supplier evaluation and selection: a literature review. Journal of Cleaner Production. v. 98, p. 66-83, 2015.

GOVINDAN, K.; KHODAVERDI, R.; JAFARIAN, A. A fuzzy multicriteria approach for measuring sustainability performance of a supplier based on triple bottom line approach. Journal of Cleaner Production, v. 47, p. 345-354, 2013.

GREEN, K. W. et al. Green supply chain management practices: Impact on performance. Supply Chain Management, v. 17, n. 3, p. 290-305, 2012.

GREEN, S.; MAY, S. Re-engineering construction: going against the grain. Building Research and Information, v. 31, n. 2, p. 97-106, 2003.

GRIMSHAW, J. A guide to knowledge synthesis: a knowledge synthesis chapter. Ottawa: Canadian Institutes of Health Research, 2008. Available: http://www.cihr-irsc.gc.ca/e/41382.html. Access: 15 abr. 2021.

HAFEEZ, K. et al. Systems design of a two-echelon steel industry supply chain. International Journal of Production Economics, v. 45, n. 1-3, p. 121-130, 1996.

HAIR, J. F.; RINGLE, C. M.; SARSTEDT, M. PLS-SEM: indeed a silver bullet. Journal of Marketing Theory and Practice, v. 19, n. 2, p. 139-152, 2011.

HARZING, A. W. A longitudinal study of Google Scholar coverage between 2012 and 2013.

Scientometrics, v. 98, n. 1, p. 565-575, 2014.

HE, Q.; WANG, G. Hotspots evolution and frontier analysis of lean construction research: integrated scientometric analysis using the web of science and scopus databases. Frontiers of Engineering Management, v. 2, n. 2, p. 141-147, 2015.

HENSELER, J.; RINGLE, C. M.; SARSTEDT, M. A new criterion for assessing discriminant validity in variance-based structural equation modeling. Journal of the Academy of Marketing Science, v. 43, n. 1, p. 115-135, 2015.

IRIZARRY, J.; KARAN, E. P.; JALAEI, F. Integrating BIM and GIS to improve the visual monitoring of construction supply chain management. Automation in Construction, v. 31, p. 241-254, 2013.

KHALFAN, M. M. A.; MCDERMOTT, P.; SWAN, W. Building trust in construction projects. Supply Chain Management, v. 12, n. 6, p. 385-391, 2007.

KIM, S.-Y.; NGUYEN, V. T. Supply chain management in construction: critical study of barriers to implementation. International Journal of Construction Management, p. 1-10, 2020.

KIRCHHERR, J.; REIKE, D.; HEKKERT, M. Conceptualizing the circular economy: an analysis of 114 definitions. Resources, Conservation and Recycling, v. 127, p. 221-232, 2017.

KLEINBERG, J. Bursty and hierarchical structure in streams. Data Mining and Knowledge Discovery, v. 7, n. 4, p. 373-397, 2003

KOUFTEROS, X. A.; EDWIN CHENG, T. C.; LAI, K. H. "Black-box" and "gray-box" supplier integration in product development: antecedents, consequences and the moderating role of firm size. Journal of Operations Management, v. 25, n. 4, p. 847-870, 2007.

362 Krainer, J. A.; Krainer, C. W. M.; Vidolin, A. C.; Hasse, F. K.; Romanel, F. B.; Romano, C. A. 
KUCUKVAR, M.; TATARI, O. Towards a triple bottom-line sustainability assessment of the US construction industry. The International Journal of Life Cycle Assessment. v. 18, n. 5, p. 958-972, 2013.

LEVAC, D.; COLQUHOUN, H.; O’BRIEN, K. K. Scoping studies: advancing the methodology. Implementation Science, v. 5, n. 1, p. 69-78, 2010.

LIEDER, M.; RASHID, A. Towards circular economy implementation: a comprehensive review in context of manufacturing industry. Journal of Cleaner Production, v. 115, p. 36-51, 2016.

LOVE, P. E. D.; IRANI, Z.; EDWARDS, D. J. A rework reduction model for construction projects. IEEE Transactions on Engineering Management, v. 51, n. 4, p. 426-440, 2004b.

LOVE, P. E. D.; IRANI, Z.; EDWARDS, D. J. A seamless supply chain management model for construction. Supply Chain Management, v. 9, n 1, p. 43-56, 2004 a.

LU, W.; HUANG, G. Q.; LI, H. Scenarios for applying RFID technology in construction project management. Automation in Construction, v. 20, n. 2, p. 101-106, 2011.

MARTÍN-MARTÍN, A. et al. Google Scholar, Web of Science, and Scopus: a systematic comparison of citations in 252 subject categories. Journal of Informetrics, v. 12, n. 4, p. 1160-1177, 2018.

MATHIYAZHAGAN, K. et al. An ISM approach for the barrier analysis in implementing green supply chain management. Journal of Cleaner Production, v. 47, p. 283-297, 2013.

MENG, X. The effect of relationship management on project performance in construction. International Journal of Project Management, v. 30, n. 2, p. 188-198, 2012.

MIDDLEMISS, L.; PARRISH, B. D. Building capacity for low-carbon communities: The role of grassroots initiatives. Energy Policy, v. 38, n. 12, p. 7559-7566, 2010.

MITKUS, S.; TRINKŪNIENE, E. Models of indicator systems of construction contraction agreements. Journal of Civil Engineering and Management, v. 12, n. 4, p. 327-335, 2006.

MOHER, D.; STEWART, L.; SHEKELLE, P. All in the family: systematic reviews, rapid reviews, scoping reviews, realist reviews, and more. Systematic Reviews, v. 4, n. 1, p. 1-2, 2015.

O'BRIEN, W. J. Construction supply-chain management: a vision for advanced coordination, costing, and control. In: BERKELY-STANFORD CONSTRUCTION ENGINEERING AND MANAGEMENT WORKSHOP: DEFINING A RESERCH AGENDA FOR AEC PROCESS/PRODUCTO DEVELOPMENTO IN 200 AND BEYOND, Berkely, 1999. Proceedings [...] Berkley: University of California, 1999.

O'BRIEN, W.; LONDON, K.; VRIJHOEF, R. Construction supply chain modeling : a research review and interdisciplinary research agenda. ICFAI Journal of Operations Management, v. 3, n. 3, p. 64-84, 2004.

ONAT, N. C.; KUCUKVAR, M.; TATARI, O. Scope-based carbon footprint analysis of US residential and commercial buildings: an input-output hybrid life cycle assessment approach. Building and Environment, v. 72, p. 53-62, 2014.

PETERSEN, K.; VAKKALANKA, S.; KUZNIARZ, L. Guidelines for conducting systematic mapping studies in software engineering: an update. Information and Software Technology, v. 64, p. 1-18, 2015

PETTICREW, M.; ROBERTS, H. Systematic reviews in the social sciences: a practical guide. New York : John Wiley \& Sons, 2008.

PRINS, A. A. M. et al. Using google scholar in research evaluation of humanities and social science programs: A comparison with web of science data. Research Evaluation, v. 25, n. 3, p. 264-270, 2016.

SAAD, M.; JONES, M.; JAMES, P. A review of the progress towards the adoption of supply chain management (SCM) relationships in construction. European Journal of Purchasing and Supply Management, v. 8, n. 3, p. 173-183, 2002.

SARKIS, J.; ZHU, Q.; LAI, K. H. An organizational theoretic review of green supply chain management literature. International Journal of Production Economics, v. 130, n. 1, p. 1-15, 2011.

SAUNDERS, M.; LEWIS, P.; THORNHILL, A. Research methods for business students. $5^{\text {th }}$ ed. London: FT Prentice-Hall, 2009.

SEYFANG, G. Community action for sustainable housing: building a low-carbon future. Energy Policy, v. 38, n. 12, p. 7624-7633, 2010. 
SEZEN, B. Relative effects of design, integration and information sharing on supply chain performance. Supply Chain Management, v. 13, n. 3, p. 233-240, 2008.

SHIN, T. H. et al. A service-oriented integrated information framework for RFID/WSN-based intelligent construction supply chain management. Automation in Construction, v. 20, n. 6, p. 706-715, 2011.

SPINAK, E. Dicionário enciclopédico de bibliometría, cienciometría e informetría. Montevidéu: Unesco, 1996.

TAH, J. H. M. Towards an agent-based construction supply network modelling and simulation platform. Automation in Construction, v. 14, n.3 , p. 353-359, 2005.

TAH, J. H. M.; CARR, V. Towards a framework for project risk knowledge management in the construction supply chain. Advances in Engineering Software, v. 32, n. 10-11, p. 835-846, 2001.

TIWARI, R.; SHEPHERD, H.; PANDEY, R. K. Supply chain management in construction: a literature survey. International Journal of Management Research and Business Strategy, v. 3, n. 1, p. 7-28, 2014.

TRANFIELD, D.; DENYER, D.; SMART, P. Towards a methodology for developing evidence-informed management knowledge by means of systematic review. British Journal of Management, n. 14, p. 207222, 2003.

TRICCO, A. C. et al. PRISMA extension for scoping reviews (PRISMA-ScR): checklist and explanation. Annals of Internal Medicine, v. 169, n. 7, p. 467-73, 2018.

TSERNG, H. P. et al. Mobile construction supply chain management using PDA and bar codes. Journal of Computer-Aided Civil and Infrastructure Engineering, v. 20, n. 4, p. 242-264, 2005.

TSERNG, H. P.; LIN, P. H. An accelerated subcontracting and procuring model for construction projects. Automation in Construction, v. 11, n. 1, p. 105- 125, 2002.

UTAMA, W. P. et al. Review of research trend in international construction projects: a bibliometric analysis. Construction Economics and Building, v. 16, n. 2, p. 71-82, 2016.

VIJAYASARATHY, L. R. Supply integration: an investigation of its multi-dimensionality and relational antecedents. International Journal of Production Economics, v. 124, n. 2, p. 489-505, 2010.

VOLK, R.; STENGEL, J.; SCHULTMANN, F. Building Information Modeling (BIM) for existing buildings: literature review and future needs. Automation in Construction, v. 38, p. 109-127, 2014

VONDEREMBSE, M. A. et al. Designing supply chains: Towards theory development. International Journal of Production Economics, v. 100, n. 2, p. 223-238, 2006.

VOORDIJK, H.; MEIJBOOM, B.; DE HAAN, J. Modularity in supply chains: a multiple case study in the construction industry. International Journal of Operations and Production Management, v. 26, n. 6, p. 600-618, 2006.

VRIJHOEF, R.; KOSKELA, L. The four roles of supply chain management in construction. European Journal of Purchasing and Supply Management, v. 6, n. 3-4, p. 169-178, 2000.

WALKER, G. et al. Harnessing community energies: explaining and evaluating community-based localism in renewable energy policy in the UK. Global Environmental Politics, v. 7, n. 2, p.64-82, 2007.

WANG, L. C.; LIN, Y. C.; LIN, P. H. Dynamic mobile RFID-based supply chain control and management system in construction. Advanced Engineering Informatics, v. 21, n. 4, p. 377-390, 2007.

WEBSTER, J.; WATSON, R. T. Analyzing the past to prepare for the future: writing a literature review. MIS Quarterly, v. 26, n. 2, p. 13-23, 2002.

WONG, A. Total quality management in the construction industry in Hong Kong: a supply chain management perspective. Total Quality Management, v. 10, n. 2, p. 199-208, 1999.

XUE, X. et al. An agent-based framework for supply chain coordination in construction. Automation in Construction, v. 14, n. 3, p. 413-43, 2005.

XUE, X. et al. Coordination mechanisms for construction supply chain management in the Internet environment. International Journal of Project Management, v. 25, n. 2, p. 150-157, 2007.

YAZDANI, M. et al. Integrated QFD-MCDM framework for green supplier selection. Journal of Cleaner Production, v. 142, part 4, p. 3728-3740, 2017.

364 Krainer, J. A.; Krainer, C. W. M.; Vidolin, A. C.; Hasse, F. K.; Romanel, F. B.; Romano, C. A. 
Jefferson Augusto Krainer

Programa de Pós-Graduação em Engenharia Civil | Universidade Tecnológica Federal do Paraná | Av. Dep. Heitor de Alencar Furtado, 5000 | Curitiba - PR - Brasil | CEP 81280-340 | Tel.: (41) 3279-6837 | E-mail: jeffkrainer@onda.com.br

Christiane Wagner Mainardes Krainer

Programa de Pós-Graduação em Engenharia Civil | Universidade Tecnológica Federal do Paraná | E-mail: chriswmk70@gmail.com

Ana Celia Vidolin

Programa de Pós-Graduação em Engenharia Civil | Universidade Tecnológica Federal do Paraná | E-mail: anavidolin@gmail.com

Frank Kiyoshi Hasse

Programa de Pós-Graduação em Engenharia Civil | Universidade Tecnológica Federal do Paraná | E-mail: fkhasse@uem.br

Fabiano Barreto Romanel

Programa de Pós-Graduação em Engenharia Civil | Universidade Tecnológica Federal do Paraná | E-mail: fabiano.romanel@gmail.com

Cezar Augusto Romano

Programa de Pós-Graduação em Engenharia Civil | Universidade Tecnológica Federal do Paraná | E-mail: caromano@utfpr.edu.br

\section{Ambiente Construído}

Revista da Associação Nacional de Tecnologia do Ambiente Construído

Av. Osvaldo Aranha, $99-3^{\circ}$ andar, Centro

Porto Alegre - RS - Brasil

$$
\text { CEP } 90035-190
$$

Telefone: +55 (51) 3308-4084

www.seer.ufrgs.br/ambienteconstruido

www.scielo.br/ac

E-mail: ambienteconstruido@ufrgs.br

(c) (i) This is an open-access article distributed under the terms of the Creative Commons Attribution License. 